\title{
Erupsi Obat Alergi di Poliklinik Kulit dan Kelamin RSUD Arifin Achmad (2011-2015)
}

\section{Allergic Drug Eruption at Dermato-Venereology Department Arifin Achmad Hospital (2011-2015)}

\author{
Olivia Makmur ${ }^{1 *}$, Yuni Eka Anggraini², Dimas Pramita Nugraha ${ }^{3}$ \\ ${ }^{1}$ Fakultas Kedokteran Universitas Riau, ${ }^{2} \mathrm{KJF}$ Kulit dan Kelamin Fakultas Kedokteran Universitas Riau, \\ ${ }^{3} \mathrm{KJF}$ Farmakologi Fakultas Kedokteran Universitas Riau
}

\begin{abstract}
ABSTRAK
Erupsi obat alergi merupakan bentuk reaksi simpang obat tipe B yang terjadi di kulit yang disebabkan oleh penggunaan obat. Tujuan dari penelitian ini adalah untuk mengetahui gambaran pasien erupsi obat alergi di Poliklinik Kulit dan Kelamin RSUD Arifin Achmad Provinsi Riau pada periode 1 Januari 2011-31 Desember 2015. Penelitian ini merupakan penelitian deskriptif retrospektif dengan menggunakan data sekunder berupa rekam medis. Sampel yang digunakan sebanyak 351 sampel yang telah sesuai dengan kriteria inklusi dan eksklusi. Pasien erupsi obat alergi paling banyak ditemukan pada perempuan (58,97\%) dibandingkan dengan laki-laki. Kelompok usia 41-60 tahun $(30,20 \%)$ merupakan kelompok usia pasien erupsi obat alergi terbanyak. Penyakit endokrin (10,54\%) merupakan penyakit penyerta yang paling banyak ditemukan pada penelitian ini dan riwayat alergi makanan ditemukan pada 4 kasus (1,14\%). Bentuk erupsi yang paling sering ditemukan adalah eritroderma $(23,93 \%)$. Obat penyebab erupsi obat alergi yang paling banyak ditemukan adalah antibiotik $(21,65 \%)$.

Kata kunci: antibiotik, erupsi obat alergi, eritoderma, profil, riwayat alergi
\end{abstract}

\begin{abstract}
Allergic drug eruption is the form of adverse drug reaction type B that occurs on skin that caused by history of taking medication. The aim of this study was to observe the profile of allergic drug reaction's patients at Dermatology and Venereology Department Arifin Achmad General Hospital from January 1st 2011-December 31st 2015. This study was a descriptive restrospective study using data from medical records. There were 351 samples fulfilled the inclusion criterias. Patient with drug eruption were found to be more common in female (58,97\%) than male. Age group of 41-60 years (30,20\%) were the common age group for allergic drug eruption. Endocrine disease (10,54\%) was the most concurrent illness found in this study and there were 4 cases that had a history of food allergic previously (1,14\%). Erythroderma (23,93\%) was the most common reaction found in this study. The most frequent drug caused allergic drug eruption in this study was antibiotic (21,65\%). Keywords: antibiotic, allergic drug eruption, allergic history, erythroderma, profil.
\end{abstract}

*Korespondensi: Olivia Makmur, email: oliviamakmur95@gmail.com

Artikel info: Online published first 25 April 2018; Received 9 September 2017; Accepted 21 Desember 2017.

DOI: https://doi.org/10.26891/jkm.v1i2.2018.51-59

Copyright @ 2018 Olivia Makmur, Yuni Eka Anggraini, Dimas Pramita Nugraha. This is an open access article distributed under the terms of the Creative Commons Attribution-NonCommercial 4.0 International License (http://creativecommons.org/licenses/by-nc/4.0/), which permits unrestricted non-commercial use, distribution, and reproduction in any medium, provided the original author and source are properly cited. 
Obat merupakan suatu substansi kimia yang berpotensi untuk mencegah maupun mengobati penyakit. ${ }^{1}$ Penggunaan obat tersebut dapat menimbulkan reaksi yang tidak kita inginkan, walaupun dengan dosis dan indikasi yang sesuai. Hal ini yang biasa kita sebut dengan adverse drug reactions (ADR). ${ }^{2}$ Adverse drug reaction merupakan penyebab kematian kelima terbanyak di dunia dan memiliki angka rawatan sebanyak $5-8 \%$ di seluruh dunia. ${ }^{3}$

Cutaneous Adverse Drug Reaction (CADR) atau disebut juga erupsi obat adalah suatu reaksi yang dapat menyebabkan perubahan struktur atau fungsi pada kulit dan mukosa yang disebabkan karena penggunaan obat. ${ }^{3}$ Reaksi ini merupakan jenis ADR tersering (30-45\%) yang dialami oleh $2 \%$ pasien rawat inap dan $1 \%$ pasien rawat jalan. ${ }^{3-5}$ Penelitian secara cross sectional di ADR Monitoring Center Gauhati Medical College and Hospital (GMCH), India menyatakan bahwa incidence rate pasien erupsi obat adalah $7,02 \%$ dimana mengalami peningkatan yang cukup tinggi dibandingkan 1 tahun sebelumnya yaitu $2,6 \%{ }^{6}$ Seseorang yang imunokompromais berisiko mendapatkan erupsi obat 10 kali lebih besar dibandingkan orang yang normal. ${ }^{4}$ Erupsi obat dapat terjadi melalui 2 proses, yaitu secara imunologi dan nonimunologi. Erupsi obat yang terjadi karena proses imunologi disebut dengan erupsi obat alergi. ${ }^{7}$ Bentuk erupsi obat alergi yang sering ditemui adalah eksantema morbiliformis, urtikaria, eritroderma, fixed drug eruption (FDE) dan fotosensitifitas. ${ }^{4}$ Erupsi obat dapat bermanifestasi dengan parah dan menjadi hal yang mengancam jiwa. Hal ini disebut dengan severe cutaneous adverse drug reaction (SCAR). Beberapa bentuk erupsi yang timbul adalah Sindrom Steven Johnson/Nekrolisis Epidermal Toksik (SSJ/NET), eritroderma, drug with eosinophilia and systemic symptoms (DRESS), acute generalized exanthematous pustulosis (AGEP), angioudem, dan vaskulitis. ${ }^{3}$ Penelitian yang dilakukan di Rumah Sakit Sultanah Aminah, Malaysia pada tahun 2011 menyatakan NET memiliki angka kematian (mortality rates) tertinggi, yaitu sebesar $28,6 \%$, diikuti oleh DRESS $(5,9 \%)$ dan SSJ (2,2\%). ${ }^{8}$

Faktor risiko terjadinya erupsi obat bermacammacam, untuk menegakkan diagnosis erupsi obat, harus ada riwayat menggunakan obat beberapa waktu sebelumnya. Satu bentuk erupsi dapat disebabkan oleh beberapa jenis obat dan satu jenis obat dapat menyebabkan beberapa bentuk erupsi. ${ }^{7}$ Hal ini sesuai dengan hasil penelitian di Johor, Malaysia pada tahun 2011 dimana SSJ atau NET paling sering disebabkan oleh penggunaan karbamazepin, alupurinol dan kotrimoksazol, sedangkan alupurinol juga bertanggungjawab atas munculnya DRESS. ${ }^{8}$ Penyebab erupsi obat alergi yang tersering adalah antibiotik, Obat Anti Inflamasi Non Steroid (OAINS) dan antikonvulsi. ${ }^{4}$ Hasil penelitian deskriptif yang dilakukan di Iran pada tahun 2014, dimana antikonvulsi (51,8\%) menjadi penyebab erupsi obat yang paling banyak ditemukan, kemudian antibiotik (33,7\%) dan OAINS $(5,7 \%)$. Bentuk erupsi yang sering ditemukan pada penelitian tersebut adalah SSJ (32\%), eksantema $(24,5 \%)$ dan NET (11\%). ${ }^{9}$

Penelitian secara cross sectional dilakukan di Gauhati Medical College and Hospital (GMCH) tahun 2013 mendapatkan bahwa jenis kelamin yang sering mendapatkan erupsi obat adalah perempuan dengan kelompok usia 21-40 tahun. ${ }^{6}$ Hasil penelitian tersebut sesuai dengan hasil penelitian yang dilakukan oleh Mokhtari, dkk di Isfahan, Iran pada tahun 2014 dimana perempuan merupakan jenis kelamin terbanyak menderita erupsi obat alergi dan kelompok usia 21-40 tahun (38,17\%) merupakan kelompok usia terbanyak pasien erupsi obat alergi. ${ }^{9}$ Kedua penelitian tersebut berbeda dengan hasil penelitian yang dilakukan oleh Choon, dkk di Johor Bahru, Malaysia pada tahun 2011 dimana rasio pasien erupsi obat perempuan dan laki-laki adalah $1: 1,14{ }^{8}$ Variasi hasil penelitian yang dilakukan dapat berhubungan dengan adanya pola penggunaan obat yang berbeda di setiap daerah.

Penyakit penyerta dan adanya riwayat alergi juga dapat menjadi salah satu faktor risiko terjadinya erupsi obat alergi. Beberapa penyakit dapat timbul bersamaan dengan terjadinya erupsi alergi. Contohnya adalah erupsi makulopapular yang disebabkan oleh penggunaan ampisilin biasanya diikuti dengan adanya infeksi Ebstain Barr Virus. ${ }^{10}$

Penelitian ini menjadi penting untuk dilakukan, karena adanya peningkatan angka pasien erupsi obat alergi di beberapa penelitian. Salah satunya adalah penelitian yang dilakukan oleh Susilawati dkk di Rumah Sakit Cipto Mangunkusumo yang mengambil dua periode waktu. Penelitian pertama mendapatkan hasil bahwa ada 65 pasien yang mengalami erupsi obat alergi pada tahun 2001. Penelitian selanjutnya mendapatkan hasil ada 96 kasus mengenai alergi obat pada tahun $2011 .^{5}$ Sampai saat ini gambaran pasien erupsi obat alergi di RSUD Arifin Achmad Provinsi Riau belum diketahui secara pasti. Hal ini membuat penulis ingin melakukan penelitian mengenai gambaran kasus 
erupsi obat yang terjadi di RSUD Arifin Achmad Provinsi Rlau. Tujuan dari penelitian ini adalah untuk mengetahui gambaran pasien erupsi obat alergi akibat pemakaian obat di Poliklinik Kulit dan Kelamin RSUD Arifin Achmad Provinsi Riau.

\section{METODE}

Penelitian ini memiliki desain penelitian deskriptif dengan pendekatan retrospektif, yaitu dengan cara melihat rekam medis pasien yang didiagnosis erupsi obat dari 1 Januari 2011 hingga 31 Desember 2015. Pengambilan data akan dilakukan pada Maret November 2016 dengan mengambil data rekam medis dari 1 Januari 2011 hingga 31 Desember 2015. Tempat melakukan penelitian ini adalah di RSUD Arifin Achmad, Provinsi Riau.

Populasi dalam penelitian ini adalah seluruh rekam medis pasien yang mengalami erupsi obat pada tahun 2011 hingga 2015 di RSUD Arifin Achmad. Sampelnya adalah seluruh rekam medis pasien pasien erupsi obat alergi pada tahun 2011 hingga 2015 di RSUD Arifin Achmad sesuai dengan kriteria inklusi dan ekslusi. Kriteria inklusi meliputi rekam medis yang memuat jenis kelamin, usia, riwayat penyakit alergi, penyakit penyerta, jenis erupsi obat dan golongan obat pasien erupsi obat alergi. Rekam medis yang memiliki kurang dari 3 kriteria inklusi yang disebutkan sebelumnya menjadi kriteria eksklusi pada penelitian ini.

Variabel dalam penelitian ini adalah karakteristik pasien, jenis erupsi obat, golongan obat yang dikonsumsi. Pengumpulan data menggunakan data sekunder dengan cara melihat rekam medis pasien erupsi obat pada bagian kulit dan kelamin. Metode yang digunakan dalam pengumpulan data adalah total sampling. Pengolahan data dilakukan secara manual, yaitu dengan mencatat data dari rekam medik pasien yang didiagnosis erupsi obat. Nomor rekam medis didapatkan dengan memasukkan kode International Statistical Classification of Diseases and Related Health Problems revisi ke 10 (ICD 10). Sampel tersebut telah dikelompokkan sesuai variabel penelitian. Semua data telah diolah dan disajikan dalam bentuk grafik. Penelitian ini telah dinyatakan lolos kaji etik oleh Unit Etika Penelitian Kedokteran Universitas Riau berdasarkan Surat Keterangan Lolos Kaji Etik nomor 175/UN.19.5.1.1.8/UEPKK/2016.

\section{HASIL DAN PEMBAHASAN}

Penelitian mengenai gambaran pasien erupsi obat alergi di Poliklinik Kulit dan Kelamin RSUD Arifin
Achmad periode 1 Januari 2011 hingga 31 Desember 2015 telah dilakukan dari bulan April hingga bulan Oktober, dengan waktu pengambilan data penelitian pada bulan Agustus 2016. Jumlah populasi penelitian ini adalah 572 kasus dengan jumlah sampel sebanyak 351 kasus setelah mengikuti kriteria inklusi dan eksklusi.

Jumlah pasien erupsi obat alergi tiap tahun berbedabeda dan mengalami peningkatan jumlah. Hal ini akan dijelaskan pada Gambar 1.

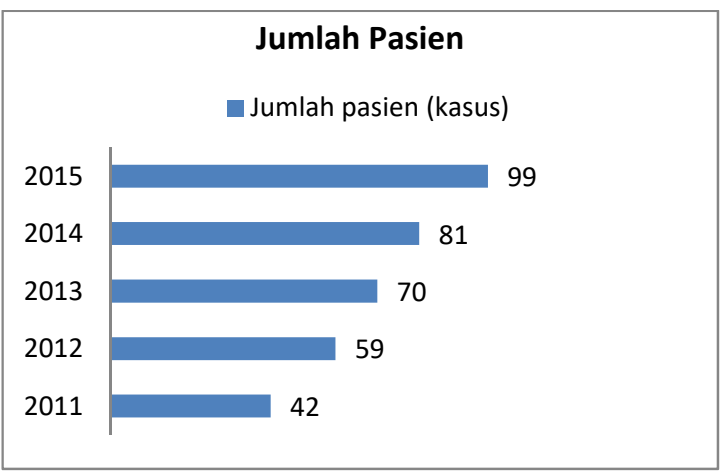

Gambar 1. Grafik Pasien Erupsi Obat Alergi

Gambar 1 menggambarkan peningkatan jumlah kasus erupsi obat alergi setiap tahun. Pada tahun 2011 kasus erupsi obat alergi berjumlah 42 kasus, tahun 2012 berjumlah 59 kasus, tahun 2013 berjumlah 70 kasus, tahun 2014 berjumlah 81 kasus dan tahun 2015 berjumlah 99 kasus.

Karakteristik dalam penelitian ini terbagi menjadi 2 variabel, yaitu jenis kelamin dan usia. Kedua variabel tersebut akan dijelaskan masing-masing dalam bentuk grafik, yaitu pada Tabel 1 dan Tabel 2 mengenai jenis kelamin pasien erupsi obat alergi dan Tabel 3 dan Tabel 4 mengenai kelompok usia pasien erupsi obat alergi.

Tabel 1. Perbandingan Jenis Kelamin Pasien Erupsi Obat Alergi dari Tahun 2011-2015

\begin{tabular}{ccc}
\hline & Laki-laki & Perempuan \\
\hline $\mathbf{2 0 1 1}$ & $33.33 \%$ & $66.67 \%$ \\
$\mathbf{2 0 1 2}$ & $49.15 \%$ & $50.85 \%$ \\
$\mathbf{2 0 1 3}$ & $45.71 \%$ & $54.29 \%$ \\
$\mathbf{2 0 1 4}$ & $39.51 \%$ & $60.49 \%$ \\
$\mathbf{2 0 1 5}$ & $37.37 \%$ & $62.63 \%$ \\
\hline
\end{tabular}

Tabel 1 menggambarkan persentase jenis kelamin pasien erupsi obat alergi selama 5 tahun. Pada penelitian ini erupsi obat alergi paling banyak dialami oleh perempuan, yaitu sebanyak 207 kasus (58,15\%) dari 351 kasus. Laki-laki memiliki presentase sebanyak $41,85 \%$ dari 351 kasus. 
Pasien dengan jenis kelamin perempuan merupakan pasien erupsi obat alergi terbanyak di setiap tahunnya. Pada tahun 2011, ditemukan persentase jenis kelamin perempuan sebanyak $66,67 \%$, tahun 2012 sebanyak 50,85\%, tahun 2013 sebanyak $54,29 \%$, tahun 2014 sebanyak 60,49\%. dan tahun 2015 sebanyak 62,63\%.

Tabel 2. Kelompok Usia Pasien Erupsi Obat Alergi

\begin{tabular}{c|c}
\hline Kelompok Usia & $\mathbf{n}(\%)$ \\
\hline $0-20$ tahun & $21.94 \%$ \\
$21-40$ tahun & $29.63 \%$ \\
$41-60$ tahun & $31.20 \%$ \\
$61-80$ tahun & $16.24 \%$ \\
$\geq 81$ tahun & $1.99 \%$ \\
\hline
\end{tabular}

Usia pasien erupsi obat alergi disajikan dengan cara berkelompok, dengan rentang 20 tahun. Kelompok usia pasien erupsi obat alergi terbanyak adalah usia 41-60 tahun yaitu sebanyak 106 kasus (30,20\%) dan paling jarang ditemukan pada usia lebih atau sama dengan 81 tahun yaitu sebanyak 7 kasus (1,99\%).

Perbandingan kelompok usia di masing-masing tahun adalah sebagai berikut usia di bawah 21 tahun paling banyak mengalami erupsi obat pada tahun 2015, yaitu sebanyak 29,29\%. Pasien dengan kelompok usia 21-40 tahun paling banyak mengalami erupsi obat alergi pada tahun 2012 yaitu sebanyak $33,90 \%$. Pasien dengan kelompok usia 41-60 tahun paling banyak mengalami erupsi pada tahun 2014 yaitu sebanyak $34,57 \%$. Pasien dengan kelompok usia 61-80 tahun paling banyak ditemukan pada tahun 2013 dengan persentase 22,86\% dan pasien di atas usia 80 tahun paling banyak ditemukan pada tahun 2014 dengan persentase 3,70\%.

Gambaran penyakit penyerta pada pasien erupsi obat alergi ditampilkan dalam 2 tabel, yaitu Tabel 3 menggambarkan penyakit penyerta sesuai dengan sistem organ manusia dan Tabel 4 membagi penyakit penyerta menjadi infeksi dan noninfeksi.

Penyakit penyerta pada pasien erupsi obat alergi tidak semuanya yang tercantum dalam rekam medis pasien. Data yang terkumpul adalah sebanyak 189 kasus dari 351 kasus (53,85\%). Gangguan pada sistem endokrin merupakan penyakit penyerta berdasarkan sistem yang paling banyak ditemukan dalam penelitian ini yaitu sebanyak 37 kasus $(10,54 \%)$. Gangguan pada obstetri dan ginekologi merupakan penyakit penyerta yang paling jarang ditemukan dalam penelitian ini, yaitu sebanyak 1 kasus $(0,28 \%)$.
Tabel 3. Penyakit Penyerta pada Pasien Erupsi Obat Alergi

\begin{tabular}{lc}
\hline \multicolumn{1}{c}{ Penyakit Penyerta } & $\mathbf{n}(\mathbf{\%})$ \\
\hline Dermatologi & $4.27 \%$ \\
Endokrin & $10.54 \%$ \\
Gastrointestinal & $5.13 \%$ \\
Hematologi & $0.85 \%$ \\
Imunologi & $1.99 \%$ \\
Kardiovaskular & $7.41 \%$ \\
Muskuloskletal & $4.27 \%$ \\
Neoplasma & $1.99 \%$ \\
Neurologi & $3.42 \%$ \\
Obstetri dan ginekologi & $0.28 \%$ \\
Ophtalmologi & $2.56 \%$ \\
Respirasi & $5.13 \%$ \\
THT & $2.56 \%$ \\
Urologi & $2.85 \%$ \\
Venerologi & $0.57 \%$ \\
Tidak ada data & $46.15 \%$ \\
\hline
\end{tabular}

Tabel 4. Distribusi penyakit penyerta berdasarkan infeksi dan noninfeksi

\begin{tabular}{l|l}
\hline \multicolumn{1}{c}{ Penyakit Penyerta } & n (\%) \\
\hline Infeksi & $25.07 \%$ \\
Noninfeksi & $28.78 \%$ \\
Tidak diketahui & $46.15 \%$ \\
\hline
\end{tabular}

Peneliti juga membagi penyakit penyerta menjadi 2 kelompok besar, yaitu penyakit infeksi dan noninfeksi. Penyakit non infeksi merupakan penyakit penyerta yang paling banyak ditemukan dalam penelitian ini, yaitu sebanyak 101 kasus $(28,78 \%)$. Penyakit infeksi memiliki frekuensi sebanyak 88 kasus dari 189 kasus penyakit penyerta yang ditemukan (25,07\%).

Tabel 5. Riwayat penyakit alergi pasien erupsi obat alergi

\begin{tabular}{lc}
\hline Riwayat alergi & $\mathbf{n ~ ( \% )}$ \\
\hline Udara dingin & $0.85 \%$ \\
Asma & $0.85 \%$ \\
Alergi makanan & $1.14 \%$ \\
Tidak diketahui & $97.15 \%$ \\
\hline
\end{tabular}

Tidak semua pasien erupsi obat alergi memiliki riwayat alergi. Rekam medis yang memiliki catatan riwayat alergi pada pasien berjumlah 10 kasus dari 351 kasus (2,85\%). Alergi terhadap makanan merupakan alergi yang paling banyak ditemukan, yaitu sebanyak 4 kasus $(1,14 \%)$. Alergi terhadap udara dingin dan asma masing-masing memiliki jumlah kasus yang sama, yaitu 3 kasus $(0,85 \%)$.

Terdapat 12 bentuk erupsi obat yang diteliti oleh penulis yaitu eritema, urtikaria, vaskulitis alergi, purpura, eksem, eritroderma, FDE, NET, fotosensitivitas, eritema multiforme, SSJ dan erupsi morbiliformis. Keduabelas bentuk tersebut kemudian dicari berdasarkan kode ICD 10 di RSUD 
Arifin Achmad, dan ada 2 bentuk erupsi yang tidak memiliki kode ICD 10, yaitu toxic erythema dan erupsi morbiliformis. Bentuk erupsi berupa purpura dan NET tidak ditemukan data rekam medis yang memiliki diagnosis tersebut.

Tabel 6. Bentuk-bentuk erupsi obat alergi

\begin{tabular}{lc}
\hline Bentuk Erupsi Obat Alergi & $\mathbf{n}(\%)$ \\
\hline Dermatitis alergika & $0.57 \%$ \\
Eksem & $9.69 \%$ \\
Eritema multiforme & $1.14 \%$ \\
Eritroderma & $23.93 \%$ \\
FDE & $21.08 \%$ \\
Fotosensitif alergi & $0.28 \%$ \\
SSJ & $9.12 \%$ \\
Urtikaria & $18.80 \%$ \\
Urtikaria alergi & $3.70 \%$ \\
Urtikaria angioudema & $1.42 \%$ \\
Vaskulitis alergika & $0.57 \%$ \\
Tidak diketahui bentuknya & $8.83 \%$ \\
SSJ + eritroderma & $0.85 \%$ \\
\hline
\end{tabular}

Beberapa bentuk erupsi yang memiliki kode ICD di RSUD Arifin Achmad dan ditemukan rekam medisnya adalah dermatitis alergika, eksem, eritema multiforme, eritroderma, Fixed Drug Eruption (FDE), fotosensitif alergika, Sindrome Steven Johnson (SSJ), urtikaria, urtikaria alergi, urtikaria angioudema dan vaskulitis alergika. Ada juga rekam medis yang tidak mencantumkan bentuk erupsi yang dialami oleh pasien tersebut. Beberapa pasien juga menunjukkan 2 bentuk erupsi sekaligus, yaitu SSJ dan eritroderma. Eritroderma merupakan bentuk erupsi terbanyak yang ditemukan, yaitu sebanyak 89 kasus $(25,00 \%)$, diikuti dengan FDE sebanyak 74 kasus $(20,79 \%)$ dan urtikaria sebanyak 66 kasus (18,54\%). Fotosensitif alergika merupakan bentuk yang paling jarang ditemukan, yaitu sebanyak 1 kasus $(0,28 \%)$.

Obat penyebab erupsi obat alergi telah digolongkan menurut golongannya. Tabel 9 akan menjelaskan mengenai golongan-golongan obat tersebut.

Penyebab erupsi obat alergi tidak dapat ditentukan pada semua kasus, dari 351 kasus hanya 169 kasus $(48,15 \%)$ yang ditemukan obat penyebabnya. Tiga penyebab terbanyak yaitu antibiotik $(21,65 \%)$, Obat Anti Inflamasi Non-Steroid /OAINS (4,56\%) dan analgesik $(4,27 \%)$. Penyebab yang paling jarang ditemukan adalah anastesi yaitu sebanyak 1 kasus $(0,28 \%)$.

Erupsi obat alergi di RSUD Arifin Achmad mengalami peningkatan jumlah kasus erupsi obat alergi setiap tahunnya dari tahun 2011-2015 dengan kasus terbanyak terjadi di tahun 2015 yaitu sebanyak 99 kasus. Hal ini sesuai dengan hasil penelitian
Susilawati, dkk di RSCM yang menyatakan bahwa terjadi peningkatan pasien erupsi obat alergi. ${ }^{5}$

Tabel 7. Obat penyebab erupsi obat alergi

\begin{tabular}{l|c}
\hline Obat Penyebab Erupsi Obat Alergi & $\mathbf{n}(\%)$ \\
\hline Analgesik & $4.27 \%$ \\
Anastesi & $0.28 \%$ \\
Antibiotik & $21.65 \%$ \\
Antidiabetes & $1.71 \%$ \\
Antifungi & $1.14 \%$ \\
Antigout & $0.85 \%$ \\
Antihistamin & $1.14 \%$ \\
Antikonvulsi & $1.14 \%$ \\
Antilipidemik & $0.57 \%$ \\
ARV & $0.85 \%$ \\
OAINS & $4.56 \%$ \\
Tidak mengetahui jenis obatnya & $3.70 \%$ \\
Obat jantung dan hipertensi & $3.13 \%$ \\
Obat sistem pencernaan & $2.28 \%$ \\
Obat sistem pernapasan & $0.85 \%$ \\
Tidak ada data & $51.85 \%$ \\
\hline
\end{tabular}

Jenis kelamin terbanyak yang mengalami erupsi obat alergi menurut penelitian ini adalah perempuan, yaitu sebanyak 207 kasus (58,97\%). Hasil dari penelitian ini juga menggambarkan bahwa perempuan merupakan pasien erupsi obat alergi terbanyak setiap tahunnya. Perempuan dikatakan memiliki angka kejadian erupsi obat 35\% lebih tinggi dibandingkan laki-laki. ${ }^{4}$ Hasil ini sesuai dengan penelitian yang dilakukan oleh Mokhtari dkk ${ }^{9}$ yang menyebutkan bahwa pasien erupsi obat paling banyak dialami oleh perempuan, yaitu sebanyak 177 pasien dari 282 pasien $(60,8 \%)$. Penelitian yang dilakukan oleh Lihite $\mathrm{dkk}^{6}$ di India juga menyebutkan bahwa perempuan lebih sering mengalami erupsi obat alergi dibandingkan laki-laki, yaitu sebanyak 66 orang dari 108 orang (61,11\%). Farshchian dkk ${ }^{40}$ juga melakukan penelitian mengenai erupsi obat alergi dengan melihat data selama 2 tahun. Hasil dari penelitian tersebut adalah jenis kelamin tersering yang menderita erupsi obat alergi adalah perempuan (63\%).

Patel dkk menyatakan bahwa perempuan sering mengkonsumsi obat-obatan daripada laki-laki. ${ }^{11} \mathrm{Hal}$ ini berhubungan dengan hasil penelitian ini, dimana setiap tahun perempuan merupakan jenis kelamin terbanyak yang menderita erupsi obat alergi yang disebabkan karena penggunaan obat sebelumnya. Penelitian yang dilakukan oleh Farage dkk menyatakan bahwa perempuan secara umum memiliki usia yang panjang daripada laki-laki. ${ }^{11,12} \mathrm{Hal}$ ini kemungkinan disebabkan karena angka mortalitas laki-laki lebih tinggi dari perempuan. Penelitian mengenai jarak angka harapan hidup antara laki-laki 
dan perempuan di Korea yang dilakukan oleh Yang, $\mathrm{dkk}^{13}$ menyatakan bahwa faktor yang mempengaruhi perbedaan usia tersebut yaitu peningkatan kesehatan reproduktif pada perempuan dan tingginya angka mortalitas pada laki-laki. Beberapa penyebab peningkatan angka kematian tersebut adalah penyakit hati, penyakit yang berhubungan dengan riwayat hipertensi dan kecelakaan lalu lintas. Hormon estrogen yang dimiliki oleh perempuan menyebabkan kuatnya respons imun yang ditimbulkan, baik sistem imun humoral maupun sistem imun adaptif. Estrogen dapat meningkatkan jumlah dari IgG dan IgM, serta meningkatkan respons dari sel Th2 dengan cara merangsang pelepasan sitokin tipe 2 yang mendukung respons antibodi. Hal ini menyebabkan perempuan sebelum memasuki masa menopause lebih rentan untuk mengalami reaksi hipersensitivitas. ${ }^{12}$ Erupsi obat alergi memiliki mekanisme kerja sesuai dengan reaksi hipersensitivitas tipe I, II, III, dan IV. ${ }^{14}$ Belum ada penelitian yang menghubungkan antara pengaruh hormon estrogen dan angka kejadian erupsi obat alergi yang lebih banyak dialami oleh perempuan.

Kelompok usia yang paling banyak menderita erupsi obat alergi pada penelitian ini adalah usia 41-60 tahun yaitu sebanyak 106 kasus dari 351 kasus $(30,20 \%)$. Pembagian kelompok usia setiap tahun memiliki jumlah pasien erupsi obat alergi yang berbeda-beda. Kelompok usia 41-60 tahun paling banyak mengalami erupsi pada tahun 2014 yaitu sebanyak $34,57 \%$. Hasil penelitian tersebut sesuai dengan hasil penelitian yang dilakukan oleh Choon $\mathrm{dkk}^{8}$, dimana kelompok usia terbanyak yang mengalami erupsi obat alergi adalah 20-59 tahun. Usia dekade ketiga dan keempat merupakan kelompok usia yang paling sering ditemukan erupsi obat alergi menurut hasil penelitian yang dilakukan oleh Farshchian $\mathbf{d k k}^{15}$.

Penelitian yang dilakukan oleh Susilawati $\mathbf{d k k}^{5}$ menyebutkan beberapa faktor yang berpengaruh dalam menegakkan diagnosa FDE (salah satu bentuk erupsi obat alergi) adalah underdiagnosis, keinginan pasien untuk mengetahui penyakitnya dan intensitas sakit yang diderita pasien. Keinginan pasien untuk mengetahui penyakitnya menjadi salah satu pendorong pasien untuk mengunjungi pelayanan kesehatan. Hal ini sejalan dengan penelitian yang dilakukan oleh Saleh $\mathbf{d k k}^{16}$ dimana rentang usia yang paling banyak mengunjungi pelayanan kesehatan adalah usia 15-49 tahun.
Penelitian yang dilakukan oleh Farage $\mathrm{dkk}^{12}$ menjelaskan mekanisme imunologi yang dikaitkan dengan usia. Saat usia dewasa muda, sel $C D 4^{+}$naif banyak terdapat di sirkulasi, tetapi saat memasuki usia dewasa tua, sel $\mathrm{CD}^{+}$naif sudah berkurang jumlahnya dan digantikan oleh sel $\mathrm{CD}^{+}$memori. Hal ini mengakibatkan peningkatan produksi IL-4 yang merupakan hasil dari sel T memori. ${ }^{12}$ Mekanisme ini dapat mempermudah terjadinya reaksi hipersensitivitas tipe IV pada usia dewasa tua.

Rendahnya angka pasien erupsi obat alergi di atas usia 80 tahun disebabkan karena sudah terjadinya involusi dari respons imun dari pasien. ${ }^{10}$ Involusi dari sistem imun saat kita bertambah tua ini yang disebut dengan immunosenescence. Immunosenescence menyebabkan penurunan sistem imun yang dipengaruhi oleh berkurangnya jumlah sel T helper, sehingga terjadi penurunan respons imun. ${ }^{12}$

Penyakit penyerta pada pasien erupsi obat alergi tidak semua dicatat di dalam rekam medis pasien. Dari 351 sampel penelitian, ada 189 kasus (53,85\%) yang memiliki data mengenai penyakit penyerta pasien. Penyakit penyerta yang paling banyak ditemukan adalah gangguan pada sistem endokrin, yaitu sebanyak 37 kasus $(10,54 \%)$ dan penyakit penyerta yang paling sedikit ditemukan adalah gangguan sistem obstetri dan ginekologi yaitu sebanyak 1 kasus (0,28\%).

Pengelompokan penyakit penyerta berdasarkan jenis penyakit infeksi dan noninfeksi memiliki hasil yang hampir sama dengan pembagian sesuai dengan sistem organ. Penyakit non infeksi terjadi pada 101 kasus dari 351 kasus (28,78\%), sedangkan penyakit infeksi terjadi pada 88 kasus (25,07\%). Jumlah penyakit infeksi yang cukup banyak sesuai dengan jumlah golongan obat penyebab erupsi obat terbanyak, yaitu antibiotik.

Gangguan sistem endokrin yang paling banyak ditemukan adalah diabetes melitus, yaitu sebanyak 18 kasus $(5,13 \%)$. Hal ini dipengaruhi oleh tingginya prevalensi pasien diabetes di dunia menurut WHO pada tahun 2014, yaitu sebanyak 422 juta orang (8,5\%). Indonesia merupakan negara dengan pasien diabetes kelima tertinggi di dunia pada tahun $2014 .{ }^{17}$ Tingginya angka pasien diabetes di Indonesia ini dapat menjadikan diabetes sebagai penyakit penyerta di sebagian besar pasien erupsi obat alergi, akan tetapi tidak ada hubungan langsung antara riwayat menderita diabetes dan terjadinya erupsi obat alergi.

Dipeptidyl peptidase 4 (DPP4) merupakan protein yang ditemukan di beberapa polipeptida, salah 
satunya di permukaan sel CD26. ${ }^{18}$ Penelitian yang dilakukan oleh Ahmed, $\mathrm{dkk}^{47}$ mengenai hubungan antara tingkat DPP4 (CD26) dengan diabetes melitus tipe 2 menyebutkan bahwa terjadi peningkatan DPP4 pada pasien diabetes melitus tipe 2. Sel CD26 merupakan glikoprotein transmembran yang berfungsi sebagai imunoregulator. Sel ini memiliki peran dalam proliferasi sel T dan produksi sitokin. ${ }^{19}$ Salah satu patogenesis erupsi obat alergi memiliki mekanisme kerja yang berhubungan dengan sel $\mathrm{T}$, akan tetapi belum ada penelitian yang menyatakan adanya hubungan langsung antara diabetes melitus dan kejadian erupsi obat alergi.

Riwayat alergi pasien erupsi obat alergi pada penelitian ini hanya sebagian kecil yang tercantum di rekam medis pasien. Rekam medis yang memiliki catatan riwayat alergi pada pasien berjumlah 10 kasus dari 351 kasus (2,85\%). Ada 3 jenis alergi yang ditemukan, yaitu alergi terhadap makanan, alergi terhadap udara dingin dan asma. Alergi makanan merupakan alergi yang paling banyak ditemukan, yaitu sebanyak 4 kasus (1,14\%). Kecilnya angka tersebut menyebabkan riwayat alergi tidak dapat menjadi data yang mendukung terjadinya erupsi obat alergi dalam penelitian ini. Beberapa hal yang dapat menyebabkan tidak tercantumnya riwayat alergi pada pasien seperti tidak ditanyakan pada saat anamesis, tidak dicatat pada rekam medis pasien dan pasien tidak mengetahui apakah memiliki riwayat alergi sebelumnya.

Pada penelitian yang dilakukan di Rumah Sakit Cipto Mangunkusumo didapatkan hasil 68\% dari pasien erupsi obat alergi tidak memiliki riwayat atopi. ${ }^{5}$ Literatur lain menyebutkan bahwa seseorang yang memiliki riwayat alergi sebelumnya, memiliki kemungkinan untuk mengalami erupsi obat alergi yang lebih besar dibandingkan dengan seseorang yang tidak memiliki riwayat alergi sebelumnya. Hal ini kemungkinan terjadi karena adanya sensitisasi silang dari beberapa alergen. ${ }^{10}$

Tiga bentuk erupsi terbanyak yang ditemukan pada penelitian di RSUD Arifin Achmad adalah eritroderma, yaitu sebanyak 84 kasus (23,93\%), FDE sebanyak 74 kasus $(21,08 \%)$ dan urtikaria sebanyak 66 kasus (18,80\%). Penelitian yang dilakukan oleh Susilawati $\mathrm{dkk}^{5}$ di RSCM menemukan 3 bentuk erupsi yang paling banyak ditemukan adalah FDE (58\%), eksantema $(15,63 \%)$ dan urtikaria (12,5\%). Hasil penelitian ini hampir sama dengan yang dilakukan oleh Patel $\mathrm{dkk}^{41}$ dimana 3 bentuk erupsi tersering yang ditemukan adalah makulopapular (32,39\%), $\operatorname{FDE}(20,13 \%)$ dan urtikaria $(17,49 \%)$.
Eritroderma menjadi bentuk erupsi obat alergi yang terbanyak karena dalam penelitian ini terdapat 13 pasien yang datang dengan gejala eritroderma lebih dari 1 kali (recurrent). Penyebab berulangnya eritroderma adalah sering terjadinya eksaserbasi, sehingga pengobatan menjadi lebih sulit. ${ }^{20} \mathrm{Hal}$ ini terjadi jika eritroderma tersebut merupakan perluasan dari penyakit lainnya. Kemungkinan lainnya adalah jika terjadi reaksi silang obat yang menjadi etiologi dari eritroderma. Menurut Patel dkk, reaksi silang mudah terjadi antara obat dengan gugus beta laktam seperti penisilin, sefalosporin dan karbapenem. ${ }^{11}$

Menegakkan diagnosis eritroderma selain dengan anamesis dan pemeriksaan dermatologi juga harus didukung oleh hasil biopsi untuk mengetahui etiologi secara pasti. ${ }^{21}$ Pemeriksaan biopsi pada rekam medis tidak ada dilakukan, sehingga penentuan etiologi dari eritroderma belum tentu semuanya disebabkan karena penggunaan obat.

Pada penelitian ini, tidak semua pasien erupsi obat alergi memiliki catatan yang lengkap mengenai obat penyebabnya. Dari sampel penelitian yang berjumlah 351 kasus hanya 169 kasus (48,15\%) yang ditemukan obat penyebabnya. Tiga golongan obat terbanyak yang ditemukan adalah antibiotik sebanyak 76 kasus (21,65\%), Obat Anti Inflamasi Non-Steroid (OAINS) sebanyak 16 kasus (4,56\%) dan analgesik sebanyak 15 kasus (4,27\%).

Hasil tersebut memiliki persamaan dengan penelitian yang dilakukan oleh Choon dkk. ${ }^{8}$ dimana antibiotik merupakan penyebab erupsi obat alergi yang terbanyak, yaitu sebanyak 146 kasus (40,3\%). Penelitian yang dilakukan oleh Mokhtari dkk ${ }^{9}$ juga memiliki hasil yang mirip, dimana 3 penyebab erupsi obat alergi terbanyak adalah antikonvulsi $(51,8 \%)$, antibiotik (33,7\%) dan analgesik-OAINS (5,7\%). Hasil penelitian yang dilakukan oleh Patel $\mathrm{dkk}^{41}$ juga memberikan hasil yang tidak jauh berbeda. Antibiotik (45,46\%), OAINS (20,87\%) dan antikonvulsi (14,57\%) merupakan 3 golongan obat penyebab erupsi yang terbanyak.

Pada penelitian ini, antibiotik merupakan penyebab erupsi obat alergi yang paling sering ditemukan. Golongan antibiotik yang paling banyak ditemukan adalah golongan beta laktam, yaitu sebanyak 39 kasus $(11,11 \%)$ dengan pembagian golongan obat paling sering ditemukan adalah sefalosporin yaitu sebanyak 24 kasus (6,84\%). Sefadroksil merupakan antibiotik yang paling banyak ditemukan, yaitu sebanyak 10 kasus (2,85\%). Aspilet dan asam salisilat merupakan obat terbanyak dari golongan OAINS 
yang ditemukan dalam penelitian ini, yaitu sebanyak masing-masing 4 kasus $(1,14 \%)$. Parasetamol merupakan obat dari golongan analgesik yang paling sering ditemukan dalam penelitian ini, yaitu sebanyak 9 kasus (2,56\%).

Banyaknya penyebab erupsi obat alergi berupa antibiotik kemungkinan disebabkan oleh banyaknya pemberian antibiotik yang dilakukan di Indonesia. $\mathrm{Hal}$ ini seperti hasil yang ditemukan oleh Yuliastuti, $\mathrm{dkk}^{22}$ bahwa peresepan antibiotik di RSUD Sleman memiliki persentase sebanyak $24,09 \%$, yang relatif lebih tinggi bila dibandingkan dengan indikator WHO $(<22,70 \%)$. Literatur mengatakan bahwa reaksi silang obat mudah terjadi pada golongan penisilin, sefalosporin dan karbapenem. ${ }^{11}$ Penelitian mengenai reaksi hipersensitivitas terhadap penisilin yang dilakukan pada mencit menyatakan bahwa penisilin atau metabolitnya dapat bekerja sebagai hapten yang dapat menimbulkan respons antibodi yang spesifik. $^{23}$ Penisilin dan sefalosporin merupakan 2 golongan antibiotik yang memiliki gugus yang sama, yaitu beta laktam. Penelitian tersebut sesuai dengan hasil penelitian ini dimana golongan beta laktam merupakan penyebab terbanyak erupsi obat alergi. Obat penyebab erupsi alergi yang tidak memiliki data adalah sebanyak 52,53\%. Angka ini cukup tinggi, karena lebih dari setengah sampel tidak diketahui obat penyebab erupsi alerginya. Hal ini disebabkan karena ketidaklengkapan dari data berkas rekam medis. Penelitian mengenai kelengkapan data rekam medis yang dilakukan oleh Maharani, dkk ${ }^{24}$ menyebutkan bahwa $60 \%$ rekam medis ditemukan terisi tidak lengkap. Beberapa hal yang dapat menyebabkan ketidaklengkapan dari rekam medis adalah dari faktor lembar rekam medis, sumber daya manusia dan sarana prasarana. ${ }^{24}$ Faktor penyebab dari sumber daya manusia seperti jumlah

\section{DAFTAR PUSTAKA}

1. United Nation Office on Drugs (UNODC). Information About Drugs [homepage on the internet]. c.2015-[cited 2015 Jul 8]. Available from: http://www.unodc.org/unodc/en/illicitdrugs/definitions/

2. Schatz S, Weber R. Adverse Drug Reactions. PSAP. 2015: 6-9.

3. Verma R, Vasudevan B, Pragasam V. Severe Cutaneous Adverse Drug Reactions. Med J Armed Forces India. 2013;69(4): 375.

4. Sanmartin O. Reactive Erythemas. In: Kerdel F, Acosta F, eds. Dermatology. Singapore: McGraw Hill; 2003. p. $25-40$. sumber daya manusia yang masih kurang dan beban kerja yang banyak sehingga tidak sempat menulis data rekam medis dengan lengkap.

Faktor pasien juga memiliki andil dalam pengambilan anamesis. Beberapa pasien terkadang tidak ingat telah mengkonsumsi obat apa atau tidak mengetahui jenis obat apa yang telah dikonsumsi sebelumnya. Hal ini dibuktikan dengan adanya 13 kasus yang memiliki riwayat konsumsi obat, tetapi tidak mengetahui jenis obat yang dikonsumsinya.

\section{SIMPULAN}

Jumlah pasien erupsi obat alergi mengalami peningkatan jumlah setiap tahunnya yaitu pada tahun 2011-2015, dimana jenis kelamin terbanyak yang ditemukan adalah perempuan. Usia 41-60 tahun adalah kelompok usia terbanyak dari pasien erupsi obat alergi. Penyakit penyerta yang sering ditemukan pada pasien dengan erupsi obat alergi adalah penyakit endokrin. Eritroderma merupakan bentuk erupsi obat alergi yang paling sering ditemukan. Penggunaan antibiotik menjadi penyebab terbanyak pada erupsi obat alergi. Riwayat alergi makanan paling banyak ditemukan pada pasien dengan erupsi obat alergi.

\section{KONFLIK KEPENTINGAN}

Tidak ada

\section{UCAPAN TERIMA KASIH}

Penulis mengucapkan terima kasih kepada Rumah Sakit Umum Daerah Arifin Achmad Provinsi Rlau atas izin yang diberikan. petugas tata usaha dan rekam medis untuk kesediaan waktunya mengumpulkan data rekam medis yang dibutuhkan.
5. Susilawati A, Akib AAP, Satari HI. Gambaran Klinis Fixed Drug Eruption pada Anak di Rumah Sakit Cipto Mangunkusumo. 2014;15(5): 269-273.

6. Lihite RJ, Lahkar M. A Study on Cutaneous Adverse Drug Reactions in ADR Monitoring Centre of Tertiary Care Hospital, Guwahati. J Appl Pharm Sci. 2013; 3(3): 78-81.

7. Yogya Y. Erupsi Obat pada Pasien HIV / AIDS. 2014; 41(5): 347-51.

8. Choon SE, Lai NM. An Epidemiological and Clinical Analysis of Cutaneous Adverse Drug Reactions Seen in a Tertiary Hospital in Johor, Malaysia. Indian J Dermatology, Venereol Leprol. 2012; 78(6):734-9.

9. Mokhtari F, Nikyar Z, Naeni BA, Esfahani AA, Rahmani S. Adverse Cutaneous Drug Reactions: Eight Year 
Assessment in Hospitalized Patients. J Res Med Sci. 2014; 19(8): 720-5.

10. Thong B, Vervloet D. Drug Allergies [homepage on the internet]. Singapore: World Allergy Organization; c.2015 [updated 2014; cited 2015 Jul 31]. Available from:

http://www.worldallergy.org/professional/allergic_dis eases_center/drugallergy/.

11. Patel TK, Thakkar SH, Sharma D. Cutaneous Adverse Drug Reaction in Indian Population: A Systematic Review. Indian Dermatol Online J. 2014;5(2):1-9.

12. Farage MA, Miller KW, Maibach HI. Effect of Menopause on Autoimmune Diseases. Expert Rev Obs Gynecol. 2012;7(6):557-60.

13. Yang $S$, Khang $Y$, Chun $H$, Harper $S$, Lynch J. The Changing Gender Differences in Life Expectancy in Korea 1970-2005. Sos Sci Med. 2012;75(7):1280.

14. Aung AK, Haas DW, Hulgan T, Phillips EJ. Pharmacogenomics of Antimicrobial Agents. Pharmacogenomics. 2014; 15(15): 1903-4.

15. Farshchian M, Ansar A, Zamanian A, Rahmatpour-Rokni G, Kimyai-Asadi A, Farshchian M. Drug-Induced Skin Reactions: A 2-Year Study. Clin Cosmet Investig Dermatol. 2015:53-6.

16. Saleh PA, Amir MY, Palutturi S. Hubungan Faktor Sosial dan Psikologis dengan Pemanfaatan Pelayanan Kesehatan di RS Bhayangkara Makasar.2013:5.

17. Lancet. Europe PMC Funders Group Worldwide trends in diabetes since 1980: a pooled analysis of 751 population-based studies with 4 . 4 million participants. 2016;387(10027):31.

18. Ahmed RH, Huri HZ, Al-hamodi Z, Salem SD, Muniandy S. Serum Levels of Soluble CD26 / Dipeptidyl PeptidaseIV in Type 2 Diabetes Mellitus and Its Association with Metabolic Syndrome and Therapy with Antidiabetic Agents in Malaysian Subjects. PLoS One. 2015;10(10):112.

19. Kim SC, Schneeweiss S, Glynn RJ, Doherty M, Goldfine $A B$, Solomon DH. Dipeptidyl peptidase-4 inhibitors in Type 2 Diabetes May Reduce the Risk of Autoimmune Diseases: A Population-based Cohort Study. 2016;74(11):1975.

20. Umar SH, Kelly AP, Vinson RP, Elenitsas R, Elston DM, Patterson JW. Erythroderma (Generalized Exfoliative Dermatitis) Treatment \& Management [homepage on the internet]. c.2016-[cited 2016 Okt 27]. Available from:

http://emedicine.medscape.com/article/1106906treatment.

21. Banerjee S, Ghosh S, Mandal RK. A Study of Correlation Between Clinical and Histopathological Findings of Erythroderma in North Bengal Population. Indian Dermatol Online J. 2015;60(6):549-555.

22. Yuliastuti F, Purnomo A, Sidjaswadi R. Analisis Penggunaan Obat pada Pasien Rawat Jalan di Rumah Sakit Umum Daerah Sleman Yogyakarta Periode April 2009. Media Farmasi. 2013; 10(2):104-113.

23. Han J, Yi Y, Li C, et al. Involvement of Histamine and RhoA / ROCK in Penicillin Immediate Hypersensitivity Reactions. Nat Publ Gr. 2016:1-2

24. Maharani W, Setyowati M. Tinjauan Faktor Penyebab Ketidaklengkapan Dokumen Rekam Medis Rawat Jalan di Balai Kesehatan Paru Masyarakat (BKPM) Semarang Tahun 2015. 2015;7-10 